ENTITA : Jurnal Pendidikan Ilmu Pengetahuan Sosial dan Ilmu-Ilmu Sosial http://ejournal.iainmadura.ac.id/index.php/entita

P-ISSN:2715-7555 E-ISSN:2716-1226

\title{
Strategi Guru Ilmu Pengetahuan Sosial dalam Mengoptimalkan Aspek Afektif Peserta Didik di SMPN 8 Pamekasan
}

\author{
Agung Widiyanto Santoso \\ (Universitas Negeri Surabaya) \\ Agungwidi189@gmail.com
}

\author{
Sahrul Romadhon \\ (Institut Agama Islam Negeri Madura) \\ sahrul@iainmadura.ac.id
}

\begin{abstract}
The teacher's strategy in optimizing the affective aspects of students is a very important thing in education because the affective aspects will relate to the interests and attitudes of students in learning. This study aims to determine the strategies of social studies teachers in optimizing the affective aspects of students at SMPN 8 Pamekasan, to determine the impact of implementing the social studies teacher strategies in optimizing the affective aspects, and the supporting and inhibiting factors in the social studies teacher strategies in optimizing the affective aspects of students. This study uses a qualitative approach to the type of phenomenological research. From this research, it is known that there are several strategies that social studies teachers use in optimizing the affective aspects of students, starting from pre-learning, during learning and postlearning, all of which is done in order to get optimal learning outcomes from students at school. Keywords: Teacher Strategy, Affective Aspect, Social Studies Learning.
\end{abstract}

Abstrak

Strategi guru dalam mengoptimalkan aspek afektif peserta didik adalah sebuah hal yang sangat penting dalam pendidikan karena aspek afektif akan berkaitan dengan minat dan sikap peserta didik dalam pembelajaran. Penelitian ini bertujuan untuk mengetahui strategi guru IPS dalam mengoptimalkan aspek afektif peserta didik di SMPN 8 Pamekasan, untuk mengetahui dampak dari penerapan strategi guru IPS dalam mengoptimalkan aspek afektif, dan faktor pendukung dan penghambat dalam strategi guru IPS dalam mengoptimalkan aspek afektif peserta didik. Penelitian ini menggunakan pendekatan kualitatif dengan jenis penelitian fenomenologi. Dari penelitian ini diketahui, terdapat beberapa strategi yang dilakukan guru IPS dalam mengoptimalkan aspek afektif peserta didik yaitu dimulai dari pra pembelajaran, pada saat pembelajaran dan pasca pembelajaran, semua itu dilakukan agar mendapatkan hasil belajar dari peserta didik yang optimal di sekolah.

Kata Kunci: Strategi, Guru, Aspek Afektif, Pembelajaran IPS

Received: 21 July 2021 ;Revised: 12 November 2021 ; Accepted: 10 December 2021 


\section{Pendahuluan}

Pembelajaran adalah serangkaian proses interaksi antara peserta didik dengan guru dan sumber belajar pada suatu lingkungan belajar. Pembelajaran merupakan sebuah upaya yang diberikan oleh seorang pendidik berupa proses perolehan ilmu dan pengetahuan, pembentukan sikap dan pengusaan kemahiran pada peserta didik. Dengan kata lain, pembelajaran adalah sebuah proses untuk membantu peserta didik agar dapat belajar dengan baik Suardi, 2018).

Pembelajaran IImu Pegetahuan Sosial (IPS) merupakan integrasi dari berbagai cabang ilmu sosial dan humaniora, yaitu: sosiologi, sejarah, geografi, ekonomi, politik, hukum, dan budaya. Pembelajaran Ilmu Pengetahuan Sosial dirumuskan atas dasar realitas dan fenomena sosial yang terjadi di tengah masyarakat. Pembelajaran Ilmu Pengetahuan Sosial dikembangkan dengan tujuan utama yaitu untuk membentuk pribadi anak bangsa yang peduli terhadap kehidupan sosial dan mampu menguasai disiplin ilmu-ilmu sosial untuk mencapai sumber daya manusia yang lebih baik untuk bangsa dan negara (Ahmad Susanto Ahmad 2014).

Guru adalah seorang pendidik anak bangsa, peran seorang guru adalah sebagai "penggerak" dalam proses belajar peserta didik di sekolah, maka guru perlu memahami dan membentuk sebuah strategi dalam pembelajarannya di sekolah. Adapun aspek yang harus diberikanoleh seorang guru adalah aspek kognitif, afektif dan psikomotorik (Sugeng Widodo, 2018). Dalam peraturan pemerintah No 74 tahun 2008 tentang guru, pasal 1 ayat 1 (Peraturan Pemerintah,2008) menyebutkan bahwa guru adalah pendidik profesional dengan tugas utama, mengajar, membimbing, mendidik, menilai, melatih dan mengevaluasi peserta didik. Artinya bahwa seorang guru tidak hanya mentransfer dan mengembangkan ilmu pengetahuan semata akan tetapi memiliki peran dan tanggung jawab untuk mengoptimalkan aspek tertentu untuk mendukung keberhasilan belajar peserta didik (Septian Aji Permana, 2017).

Di dalam sebuah pendidikan terdapat tiga aspek yang harus terpenuhi yang pertama adalah aspek kognitif, yang kedua adalah aspek afektif dan yang ketiga adalah aspek psikomotor. Salah satu aspek yang perlu menjadi perhatian dan di optimalkan dalam pembelajaran ilmu pengetahuan sosial adalah aspek afektif, karena menurut Popham, Ranah afektif akan menentukan keberhasilan belajar seseorang. Artinya bahwa seorang yang tidak memiiki minat pada pembelajaran akan mangalami kesulitan dalam menyerap pembelajaran sebaliknya seorang yang memilii minat dalam pembelajaran akan mendapatkan hasil pembelajaran yang diharapkan optimal. Maka dari itu seorang guru 
harus mampu membangkitkan semangat, rasa persatuan, rasa sosial dan semangat nasionalisme peserta didik (Sudaryono,2012).

Berdasarkan informasi dari hasil wawancara guru IPS dari beberapa sekolah penyelenggara pembelajaran IPS yang ada di Pamekasan, saya meneliti tiga sekolah yakni SMPN 5 Pamekasan, SMPN 4 Pamekasan, dan SMPN 8 Pamekasan. Pada sekolah pertama mendapatkan hasil bahwa di sekolah SMPN 5 Pamekasan jika disimpulkan masih terdapat banyak hal yang harus dibenahi atau masih kurang baik jika ditinjau dari aspek afektifnya, misalkan kurangnya minat belajar peserta didik di dalam kelas, sering terlambat datang kesekolah dan kurang menjaga kebersihan kelas. Selajutnya, disekolah SMPN 4 Pamekasan jika di tinjau dari aspek afektifnya masih kurang baik, jika disimpulkan terdapat beberapa hal yang harus di benahi oleh guru, misalnya perkelahian antarteman, berkata tidak sopan di dalam kelas, bahkan ada yang bolos sekolah.Di sekolah SMPN 8 Pamekasan setelah saya mewawancarai beberapa Guru IPS mendapatkan kesimpulan bahwa di sekolah ini meskipun masih ada beberapa peserta didik yang kurang baik dari segi aspek afektifnya akan tetapi Guru IPS tetap berusaha untuk menerapkan kedisplinan yang tinggi, setiap ada kesalahan pasti Guru tersebut akan menindaknya dan hasilnya peserta didik lebih displin, bertanggung jawab dan mematuhi peraturan yang telah di terapkan di sekolah SMPN 8 Pamekasan.

Berdasarkan hasil pengamatan awal yang dilakukan melalui wawancara dan observasi langsung di lapangan yang dilaksanakan pada hari kamis tanggal 1 Oktober 2020 di sekolah SMPN 8 Pamekasan maka didapat sebuah informasi bahwasanya pada saat kegiatan belajar mengajar berlangsung khususnya dimata pelajaran IPSdidalam kelas menunjukkan bahwa banyak dari peserta didik yang sudah disiplin jika di tinjau dari aspek afektif, misalnya ketika guru menerangkan peserta didik mendengarkan dengan baik penjeasan dari guru. Selanjutnya, ketika peserta didik di dalam kelas, mereka aktif berpartisipasi dalam kegiatan belajar mengajar.

Semua itu terjadi salah satunya karena ada strategi dari guru IPS di SMPN 8 Pamekasan. Di SMPN 8 Pamekasan guru mata pelajaran IPS memiliki komitmen untuk memberikan yang terbaik baik peserta didiknya. Guru-guru IPS ini mempunyai strategi untuk mengoptimalkan aspek afektif peserta didiknya, seperti bersikap tegas terhadap peserta didik yang tidak memperhatikan ketika pembelajaran berlangsung, bertindak tegas terhadap peserta didik yang melanggar tata tertib sekolah, dan mengharuskan peserta didik untuk 
Agung Widiyanto, Sahrul Romadhon

berpenampilan rapi dan sopan ketika berada di lingkungan sekolah, bahkan masih banyak lagi yang diterapkan oleh guru IPS ketika pra-pembelajaran, pada saat pembelajaran dan pasca pembelajaran.

Selain dari hasil wawancara, beberapa penelitian terdahulu yang berhubungan dengan penelitian ini. Pertama, Penelitian yang laksanakan pada tahun 2017 oleh Muhammad Syakroni mahasiswa jurusan Pendidikan Agama Islam Fakultas Tarbiyah dan IImu Keguruan Institut Agama Islam Negeri Salatiga, dengan skripsinya yang berjudul "Strategi Pengembangan Ranah Afektif Dalam Pembelajaran Aqidah Akhlak pada Siswa Kelas VIII A di MTSN 1 Boyolali Tahun Pelajaran 2016/2017'. Penelitian ini membahas tentang Strategi Pengembangan Ranah Afektif Dalam Pembelajaran Aqidah Akhlak Pada Siswa Kelas VIIIA di MTs Negeri 1Boyolali Tahun Pelajaran 2016/2017. Fokus penelitian yang dikaji dalam penelitian ini adalah bagaimanakah strategi pengembangan ranah afektif dalam pembelajaran aqidah akhlak pada siswa kelas VIIIA di MTs Negeri 1 Boyolali tahun pelajaran 2016/2017 dan juga untuk mengetahui faktor pendukung dan factor penghambat strategi pengembangan ranah afektif dalam pembelajaran aqidah akhlak pada siswa kelas VIIIA di MTs Negeri 1 Boyolali tahun pelajaran 2016/2017.

Kedua, penelitian yang dilaksanakan pada tahun 2014 oleh Mochamat Solikin, mahasiswa jurusan Kependidikan Islam fakultas IImu Tarbiyah dan Keguruan Universitas Islam Negeri Sunan Kalijaga Yogyakarta dengan judul penelitian "Strategi Pembelajaran Afektif untuk Membentuk Karakter Bertanggungjawab bagi Santri kelas XII di Pondok Pesantren Pabelan Magelang Jawa Tengah". Hasil penelitian ini adalah (1) pelaksanaan strategi pembelajaran afektif dalam membentuk karakter bertanggung jawab bagi santri kelas XII di Pondok Pesantren Pabelan Magelang Jawa Tengah mecakup tiga hal, yaitu pendekatan, metode dan tahap-tahap pembelajaran. (2) hasil yang diperoleh dari Strategi pembelajaran afektif dalam membentuk karakter bertanggung jawab ini dikatakan berhasil, dilihat dari siswa yang mengerjakan tugas di luar jam pelajaran dan mampu mempertanggung jawabkan atas tugas yang sudah di berikan. (3) faktor pendukung dalam pelaksanaan strategi afektif diantaranya; suasana di dalam kelas yang nyaman, rasa ta'dhim santri terhadap ustadz sehingga pada saat menggunakan strategi pembelajaran afektif bisa dilakukan dengan baik dan kesadaran santri sudah tertata, sedangkan faktor penghambatnya diantaranyamasih tergodanya santri dengan lingkungan sekitar, jiwa santri yang masih labil dan terlalu penuhnya kegiatan diluar jam pelajaran, sehingga pada saat pembelajaran banyak siswa yang tidak konsentrasi dan ngantuk.

Kedua penelitian terdahulu tersebut memiliki persamaan dan perbedaan dengan penelitian ini, adapun persamaan dan perbedaannya, antara lain 1) pembahasan intinya 240

ENTITA Vol. 3 No. 2, December 2021 
sama-sama mengenai pengembangan atau pengoptimalan ranah afektif pada suatu pembelajaran di sekolah, dalam penelitian tersebut berkaitan dengan penelitian ini karena sama-sama meneliti bagaimana strategi guru mata pelajaran dapat mengembangkan aspek afektif peserta didik 2) sama-sama penelitian yang menggunakan pendekatan kualitatif.

Adapun perbedaannya adalah 1) ruang lingkup pembahasan pada penelitian terdahulu adalah Pembelajaran Aqidah Akhlak, sedangkan penelitian saat ini adalah pembelajaran IImu Pengetahuan Sosial, 2) subjek penelitian terdahulu adalah siswa kelas VIII A di MTSN 1 Boyolali sedangkan subjek penelitian saat ini adalah siswa SMPN 8 Pamekasan. Persamaan penelitian terdahulu yang dilakukan oleh Mochamat Solikin dengan penelitian ini adalah 1) konteks penelitiannya sama-sama membahas tentang strategi pembelajaran afektif yang akan di terapkan pada peserta didik di sekolah 2) sama-sama penelitian yang menggunakan pendekatan kualitatif. Adapun perbedaannya adalah: Subjek penelitian terdahulu adalah Santri kelas XII di Pondok Pesantren Pabelan Magelang Jawa Tengah sedangkan pada penelitian ini adalah peserta didik SMPN 8 Pamekasan. Maka dari itu berdasarkan dari latar belakang yang telah dijelaskan di atas, maka peneliti tertarik untuk melakukan sebuah penelitian kualitatif yang berjudul "Strategi Guru IImu Pengetahuan Sosial dalam Mengoptimalkan Aspek Afektif Peserta Didik di SMPN 8 Pamekasan".

\section{Metode}

Penelitian ini menggunakan pendekatan kualitatif. Penelitian kualitatif adalah riset yang bersifat deskriptif dan cenderung menggunakan analisis dengan pendekatan induktif. Penonjolan proses penelitian dan pemanfaatan landasan teori dilakukan agar fokus penelitian sesuai dengan fakta di lapangan. Selain itu landasan teori juga bermanfaat untuk memberikan gambaran umum tentang latar belakang penelitian dan sebagai bahan pembahasan hasil penelitian.

Sampel yang digunakan ditekankan pada kualitasnya bukan pada jumlahnya. Sampel juga dipandang sebagai sampel teoritis dan tidak representatif. Dalam penelitian kualitatif digunakan teknik observasi terlibat langsung atau riset partisipatori, seperti yang dilakukan oleh para peneliti bidang antropologi dan etnologi sehingga peneliti terlibat langsung atau berbaur dengan yang diteliti (Rukin, 2019). Melalui jenis penelitian ini peneliti turun langsung ke lapangan dengan mencari data atau fenomena di lapangan sesuai dengan permasalahan yang akan diteliti. Sehingga peneliti dapat mengetahui secara langsung bagaimana guru IPS dalam menerapkan strategi untuk mengoptimalkan aspek afektif peserta didik di SMPN 8 Pamekasan. 
Untuk mendapatkan data yang akurat dan valid, peneliti menggunakan tiga teknik pengumpulan data, yaitu observasi, wawancara, dan dokumentasi. Dalam observasi ini peneliti melakukan ativitas pengamatan terhadap kegiatan guru IPS dalam mengoptimalkan aspek afektif peserta didik ketika berada di dalam maupun di luar kelas. Pada kegiatan observasi ini dapat dilakukan dengan mengambil gambar dan rekaman suara. Adapun wawancara yang dilakukan peneliti menggunakan wawancara terstruktur. Wawancara terstruktur digunakan sebagai teknik pengumpulan data, langkah tersebut sebagai langkah agar peneliti dapat mengetahui dengan pasti tentang informasi apa yang akan diperoleh. Oleh karena itu dalam melakukan wawancara, pengumpul data telah menyiapkan instrumen penelitian berupa pertanyaan-pertanyaan tertulis yang berupa poin penting mengenai apa yang akan di teliti yang selanjutnya akan dikembangkan pertanyaan tersebut oleh peneliti. Dengan wawancara terstruktur ini setiap narasumber diberi pertanyaan dan peneliti akan mencatat sekaligus merekamnya. Selanjutnya adalah dokumentasi yang diterapkan pada penelitian ini adalah dengan mengambil gambar atau foto yang berkaitan dengan penelitian di sekolah SMPN 8 Pamekasan ini. Misalnya pengambilan gambar pada saat wawancara dengan guru IImu Pengetahuan Sosial, kepala sekolah, dan peserta didik.

\section{Hasil dan Pembahasan}

kegiatan ini dilakukan selama 3 hari sejak 11 januari 2021 sampai 13 januari 2021. Observasi dilakukan pada tanggal 11 januari 2021 dilanjukan keesokan harinya yaitu sesi wawancara yang dilakukan peneliti pada 12 januari 2021, Kemudian dilanjutkan pada tanggal 13 Januari 2021. Sedangkan proses dokumentasi, dilakukan peneliti selama proses observasi dan wawancara berlangsung. Dari hasil pengumpulan data tersebut, terdapat berbagai macam data yang diperoleh peneliti di lapangan. Oleh sebab itu, peneliti akan memaparkan hasil dari data-data yang dikumpulkan sesuai dengan masing-masing fokus permasalahan supaya pembaca dapat memahami paparan data dari hasil penelitian yang telah dilakukan oleh peneliti.

\section{Strategi guru IImu Pengetahuan Sosial dalam mengoptimalkan aspek afektif peserta didik di SMPN 8 Pamekasan}

Dalam proses mengoptimalkan aspek afektif peserta didik, guru mempunyai strategi yang terbagi menjadi tiga bagian dalam pembelajarannya, yaitu pra-pembelajaran, pada saat pembelajaran dan pascapembelajaran. Berdasarkan hasil transkrip rekaman melalui wawancara dengan ibu Nurul Hidayati selaku guru IImu Pengetahuan Sosial di SMPN 8 Pamekasan yang terangkum dalam wawancara berikut ini:

"Untuk mengoptimalkan aspek afektif peserta didik saya membagi menjadi tiga dalam kegitan pembelajaran saya, yaitu pra pembelajaran, pada saat pembelajaran dan pasca pembelajaran 
(evaluasi). Membahas tentang pra pembelajaran atau sebelum pembelajaran dimulai saya menyiapkan semua keperluan untuk kegiatan mengajar seperti rencana pelaksaan pembelajaran (RPP) dan menyiapkan media yang akan digunakan dalam pembelajaran. kemudian mengintruksikan salah satu siswa untuk memimpin doa, membaca surat pendek dan memberi salam, setelah itu saya memberikan sedikit pengantar yang didalamnya berisi motivasi belajar untuk siswa agar bersemangat dalam menerima pembelajaran, nilai sosial yang akan di hubungkan dengan pembelajaran dan berisi nilai agama agar ilmu yang saya berikan dapat bermanfaat, saya rasa untuk membuat mereka bersemangat, disiplin dan nilai-nilai agamanya ada".

"Pada saat pembelajaran sebenarnya tidak hanya melakukan transfer knowledge saja, akan tetapi dari kegiatan pembelajaran itu saya bisa menghubungkan dengan nilai-nilai sosial, terlebih lagi saya disini mengajar IPS jadi sangat bisa untuk mengoptimalkan aspek afektif peserta didik. Misalnya pada Bab pengaruh interaksi sosial terhadap kehidupan sosial dan kebangsaan, nah pada pembahasan pluralitas masyarakat Indonesia saya memberikan nilainilai sosial kepada peserta didik, saya mengajarkan toleransi terhadap sebuah perbedaan, entah itu perbedaan agama, ras, suku, budaya dan lain-lain bahwa didalam semua perbedaan itu kita harus saling menghargai dan menghormati karena kita itu tetap satu yaitu Indonesia."

\begin{abstract}
"Selanjutnya pada pascapembelajaran atau setelah pembelajaran selesai saya menyimpulkan pembelajaran yang telah disampaikan, kemudian menanyakan apa yang belum dimengerti oleh siswa, setelah itu saya mengingatkan mereka untuk terus belajar dirumah. Saya juga mempunyai strategi agar peserta didik tetap belajar di rumah dan melatih kedisplinannya yaitu dengan memberikan dia PR. sesuai dengan yang ada di K13 seorang guru harus menilai siswa didalam maupun diluar kelas, untuk itu sebagai guru saya harus selalu mengontrol mereka ketika berada diluar kelas meskipun tidak sedang dalam jadwal pembelajaran saya, misalnya ada siswa yang atributnya tidak lengkap, rambut siswa, kebersihan kelas dan sebagainya. Disekolah ini ada buku tata tertib yang digunakan untuk sebagai pedoman atau aturan yang harus ditaati oleh peserta didik, pada buku tata tertib itu terdapat peraturan yang memiliki bobot atau skor, pada skor tertentu ada sanksi yang harus diterima. Adanya buku tata tertib ini kami berharap agar siswa-siswi yang ada disini disiplin, bertangggung jawab dan berakhlak baik."
\end{abstract}

Dari tiga tahap untuk mengoptimalkan aspek afektif peserta didik diatas dapat disimpulkan bahwa dalam suatu pembelajaran seorang guru harus bisa membagi strategi untuk mengoptimalkan aspek afektif dalam pembelajarannya. dimulai dari pra pembelajaran, pada saat pembelajaran dan pasca pembelajaran yang dijelaskan sebagai berikut:

a) Pada saat pra pembelajaran guru tersebut menyiapkan rencana pelaksaan pembelajaran (RPP) kemudian menyipkan media yang akan digunakan dalam pembelajaran. Kemudian guru memberikan sedikit pengantar yang didalamnya berisikan motivasi belajar untuk peserta didik agar bersemangat dalam menerima pembelajaran.

b) Pada saat pembelajaran guru menghubungkan materi pembelajarannya dengan nilainilai sosial yang ada di tengah masyarakat. Guru menguraikan poin penting dari materi yang disampaikan agar peserta lebih bisa memahami apa yang dijelaskan. 
Agung Widiyanto, Sahrul Romadhon

c) Pada pascapembelajaran guru bisa mengawasi peserta didiknya agar sesuai dengan peraturan yang telah di terapkan disekolah tersebut. Hal tersebut dilakukan agar membentuk aspek afektif peserta didik yang optimal.

Strategi guru Ilmu Pengetahuan Sosial dalam mengoptimlakan aspek afektif peserta didik di SMPN 8 Pamekasan terbagi menjadi tiga bagian yaitu Pra pembelajaran, pada saat pembelajaran dan pascapembelajaran yang penjelasannya sebagai berikut :

\section{Prapembelajaran}

Kegiatan pendahuluan dalam pembelajaran sering pula disebut dengan Prapembelajaran. Fungsi kegiatan tersebut adalah untuk menciptakan awal pembelajaran yang efektif yang memungkinkan siswa dapat mengikuti proses pembelajaran dengan baik. Efisiensi waktudalam kegiatan pendahuluan pembelajaran perlu diperhatikan, karena waktu yang tersedia untuk kegiatan tersebut relatif singkat hanya sekitar 5 (lima) menit. Oleh karena itu, dengan waktu yang relatif singkat tersebut guru dapat menciptakan kondisi awal pembelajaran yang baik, sehingga aktivitas pada awal pembelajaran tersebut dapat mendukung proses dan hasil pembelajaran siswa .

Dari uraian di atas, menunjukan bahwa betapa pentingnya prapembelajaran atau kegiatan pendahuluan dalam proses pembelajaran dikondisikan sedemikian rupa. Supaya dapat melaksanakan kegiatan awal pembelajaran seperti yang diharapkan diatas, marilah kita kaji kegiatan-kegiatan apa saja yang perlu dilaksanakan hingga tercipta proses prapembelajaran yang efektif. Proses pembelajaran sangat dipengaruhi oleh kegiatan awal atau pendahuluan dalam pembelajaran. Oleh sebab itu kegiatan awal dalam pembelajaran harus direncanakan dan dilaksanakan secara sistematis,fleksibel, efektif, dan efisien (Toto Ruhimat, 2019)

Guru IImu Pengetahuan Sosial di SMPN 8 Pamekasan mempunyai strategi dalam memulai pembelajaran di dalam kelas. Dari data yang peneliti dapatkan guru diantaranya sebagai berikut:

a. Guru memulai pembelajaran dengan menyiapkan segala kebutuhan untuk mengajar seperti menyiapan rencana pelaksaan pembelajaran (RPP) dan menyiapkan media yang akan digunakan dalam pembelajaran hal tersebut dilakukan dengan tujuan agar pembelajaran dapat berlangsung dengan lancar dan berharap agar ilmu yang akan dipelajari dapat lebih mudah dimengerti oleh peserta didik.

b. Kemudian guru mengajak peserta didik untuk berdoa dan memberikan pengantar yang didalamnya berisikan motivasi belajar untuk peserta didik semua itu dilakukan 
agar peserta didik bersemangat dalam menerima pembelajaran dan dengan harapan agar peserta didik antusias dalam kegiatan belajar mengajar.

c. Menciptakan Sikap dan Suasana Kelas yang Menarik. Kondisi belajar dapat dipengaruhi oleh sikap guru didepan kelas. Guru harus memperlihatkan sikap yang menyenangkan supaya peserta didik tidak merasa tegang, kaku bahkan takut. Kondisi yang menyenangkan ini harus diciptakan melalui dari awal pembelajaran sehingga peserta didik akan mampu melakukan aktivitas belajar dengan penuh pecaya diri tanpa ada tekanan yang dapat menghambat kreativitas peserta didik.

d. Setelah memberikan pengantar guru mengecek kehadiran peserta didik dengan melakukan absensi. Untuk menghemat waktudalam mengecek kehadiranpeserta didik dapat dilakukandengan cara peserta didik yang hadir disuruh menyebutkan peserta didik yang tidak hadir,kemudian guru menanyakanmengapa yang bersangkutantidak hadir dan seterusnya.

e. Untuk Selanjutnya guru memperhatikan kesiapan peserta didik dengan cara mengecek buku paket pelajaran IPS apabila peserta didik tersebut tidak membawa guru akan menggabungkan peserta didik tersebut dengan teman lainnya yang membawa buku paket.

f. Kemudian guru memperhatikan kedisiplinan peserta didik dengan melihat atribut yang di pakai semua itu dilakukan agar semua peserta didik sadar akan pentingnya kerapian dalam berpakaian. Tindakan tersebut juga bertujuan untuk menanamkan kebiasaan untuk terus displin terhadap aturan yang berlaku di sekolah SMPN 8 Pamekasan.

g. Kegiatan terakhir sebelum pembelajaran dimulai peserta didik di minta untuk mengumpulkan pekerjaan rumah yang diberikan di pertemuan sebelumnya. Kegaiatan ini juga memiliki tujuan agar peserta didik tetap belajar dirumah dan melatih kedisplinan mereka.

\section{Pada saat pembelajaran}

Pada pembahasan kali ini adalah tentang kegiatan inti dalam pembelajaran. Pada saat pembelajaran memfokuskan pada proses pembentukan pengalaman belajar (learning experience) peserta didik dalam materi atau bahan pelajaran IPS, yang disusun dan direncanakan oleh guru berdasarkan pada kurikulum 2013. Pada saat pembelajaran sangat memegang peranan penting untuk mencapai tujuan pembelajaran maupun dalam membentuk kemampuan siswa yang telah ditetapkan. Pada prinsipnya pada saat 
Agung Widiyanto, Sahrul Romadhon

pembelajaran memerlukan strategi tertentu yang perlu di gunakan oleh guru secara sistematis yang memungkinkan dapat dilaksanakan dalam pembelajaran IPS.

Strategi tersebut di rancang oleh guru agar membentuk pengalaman belajar maupun kemampuan peserta didikyang perlu ditempuh melalui proses belajar yang direncanakan oleh guru. Kompetensi yang akan dicapai peserta didik harus jelas urutan dan ruanglingkupnya sehingga akan mempermudah dalam implementasi pembelajarannya.

Dalam penelitian ini terfokus kepada strategi guru dalam mengoptimalkan aspek afektif peserta didik. Strategi yang di gunakan oleh guru pada saat pembelajaran selain ingin memberikan pemahaman tentang materi pelajaran ada strategi tertentu yang di gunakan guru untuk mengoptimalkan aspek afektif peserta didik. Strategi tersebut bertujuan agar peserta didik agar mendapatkan pemahaman tentang materi-materi pelajaran dan juga peserta didik mendapatkan nilai-nilai sosial dan norma agama yang dapat di implementasikan dalam kehidupan sehari-hari peserta didik.

Langkah-langkah kegiatan pada saat pembelajaran yang berhubungan dengan aspek afektif peserta didik yang dilakukan guru IPS di SMPN 8 Pamekasan dalam pembelajaran secara sistematis sebagai berikut:

1. Memberitahukan tujuan atau garis besar materi dan kemampuan yang akan dipelajari. Kegiatan ini dilakukan oleh guru IPS sebelum membahas pelajaran dengan tujuan agar peserta didik dapat mengetahui secara garis besar materi dan kemampuan apa yang akan dipelajari oleh peserta didik. Sehingga peserta didik menyadari dan mengetahui apa yang harus dipelajari untuk mencapai tujuan tersebut. Strategi yang digunakan oleh guru IPS di SMPN 8 Pamekasan dalam menyampaikan materi, guru menyampaikannya secara lisan dan membuat peta konsep di papan tulis sehingga semua siswa dapat mengetahui bahwa materi tersebut yang akan dipelajarinya.

2. kemudian untuk mengoptimalkan aspek afektif peserta didik pada saat pembelajaran berlangsung guru memperhatikan atau melihat kesiapan peserta didik dan memastikan apakah peserta didik tersebut antusias dalam mengikuti pelajaran atau sebaliknya. Apabila ada salah satu peserta didik yang tidak mendengarkan maka guru akan menegurnya.

3. Selanjutnya untuk mengoptimalkan aspek afektif peserta didik guru memberikan materi pembelajaran dan mengintegrasikan materi pembelajaran tersebut dengan nilai-nilai sosial yang ada dalam kehidupan sehari-hari. Contohnya adalah pada pembahasan materi modernisasi dan perubahan budaya, pada materi pembahasan tersebut guru dapat memberikan pemahaman tentang cara menghadapi era globalisasi seperti saat 
ini kepada peserta didik. Guru dapat memberikan nasehat-nasehat tentang bagaimana generasi muda menyikapi perubahan zaman saat ini, agar peserta paham dan dapat menyaring kebudayaan mana yang baik untuk di ikuti dan kebudayan mana yang harus di hindari. Karena sejatinya Indonesia memiliki kebudayaan tersendiri dan semua itu harus tetap di lestarikan oleh generasi-generasi selanjutnya.

\section{Pascapembelajaran}

Pascapembelajaran adalah Kegiatan akhir yang harus dilaksanakan atas dasar perencanaan yang telah dibuat oleh guru. Guru perlu merencanakan, dan melaksanakan kegiatan akhir dan tindak lanjut secara efektif, efisien, fleksibel dan sistematis. Pascapembelajaran ini tidak hanya diartikan sebagai kegiatan untuk menutup pelajaran, tetapi juga sebagai kegiatan penilaian hasil belajar siswa dan kegiatan tindak lanjut. Kegiatan tindak lanjut harus ditempuh berdasarkan pada proses dan hasil belajar siswa. Secara umum kegiatan akhir dan tindak lanjut pembelajaran yang dilakukan oleh guru IPS dalam mengoptimalkan aspek afektif peserta didik di antaranya:

1) Menilai hasil proses belajar mengajar.

2) Memberikan tugas/latihan yang dikerjakan di rumah.

3) Memberikan motivasi dan bimbingan belajar.

4) Memperhatikan kegiatan peserta didik di luar jam pelajaran.

Pascapembelajaran adalah kegiatan akhir dalam pembelajaran yang harus dilakukan secara sistematis dan fleksibel, sehingga dalam prosesnya akan dapat menunjang optimalisasi hasil belajar siswa. Prosedur kegiatan yang perlu ditempuh, setelah melaksanakan kegiatan pra-pembelajaran dan pada saat pembelajaran, serta setelah menyimpulkan pelajaran, maka langkah selanjutnya yang harus dilaksanakan oleh guru di SMPN 8 Pamekasan adalah sebagai berikut:

1. Pada pascapembelajaran Kegiatan penilaian dalam proses belajar merupakan kegiatan mutlak yang harus dilaksanakan oleh guru dalam pembelajaran. Oleh karena itu, guru perlu memiliki kemampuan dalam menilai hasil belajar peserta didik. Penilaian belajar dalam kegiatan akhir pembelajaran, tujuannya adalah untuk mengetahui sejauhmana kemampuan peseta didik setelah mengikuti pelajaran IPS di kelas. Waktu yang tersedia untuk kegiatan pascapembelajaran ini relatif singkat, maka guru IPS perlu strategi yang dianggap tepat untuk efektivitas dan efisiensi dalam pelaksanakan penilaian. Dalam prosesnya guru IPS melaksanakan penilaian secara lisan. Contoh dari kegiatan tersebut adalahmenunjuk beberapa siswa yang dianggap representatif (mewakili) seluruh siswa. 
2. Strategi selanjutnya yang digunakan oleh guru IPS dalam mengoptimalkan aspek afektif peserta didik adalah memberikan pekerjaaan rumah atau PR agar peserta didik tetap belajar dan mengetahui sejauh mana peserta didik paham terhadap materi yang disampaikan di dalam kelas. Pekerjaan rumah yang diberikan guru pada peserta didik juga bertujuan agar peserta didik tetap disiplin dan tanggung jawab, dengan harapan setelah memberikan pekerjaan rumah tersebut peserta didik memiliki aspek afektif yang optimal.

3. Selanjutnya strategi guru dalam mengoptimalkan aspek afektif adalah memberikan motivasi dan bimbingan belajar. Kegiatan ini menjadi hal yang sangat di butuhkan oleh peserta didik karena dengan adanya motivasi yang guru sampaikan di harapkan peserta didik akan lebih bersemangat lagi dalam belajar dan dapat termotivasi untuk menggapai cita-cita yang peserta didik inginkan.

4. Stategi terakhir pada pascapembelajaran yang dilakukan guru IPS dalam proses mengoptimalkan aspek afektif peserta didik di SMPN 8 Pamekasan adalah memperhatikan kegiatan peserta didik di luar jam pelajaran. Kegiatan ini adalah sebuah strategi yang dilakukan oleh guru IPS dalam mengoptimalkan aspek afektif peserta didiknya. Contoh dari kegiatan ini adalah mengontrol kegiatan peserta didik selama jam istirahat, guru IPS akan memperhatikan setiap kelas agar tetap displin, seperti dari kebersihan kelas. apabila ada kelas yang kurang menjaga kebersihannya makan guru akan menegurnya dan akan memberikan sanksi berupa membayar uang sebesar lima ribu, uang tersebut nantinya akan di gunakan untuk pembangunan musholla sekolah. Contoh lain dari kegiatan pasca pembelajaran dalam mengoptimalkan aspek afektif peserta didik adalah guru memperhatikan kerapian berpakaian setiap peserta didik, dari kegiatan tersebut di harapkan agar peserta didik displin akan cara berpakaian yang bai

\section{Dampak strategi guru IPS dalam mengoptimalkan aspek afektif bagi peserta didik di SMPN 8 Pamekasan}

Aspek afektif berhubungan dengan minat, sikap, dan karakter yang dapat berbentuk tanggung jawab, kerjasama, disiplin, komitmen, percaya diri, jujur, menghargai pendapat orang lain, dan kemampuan mengendalikan diri. Semua kemampuan ini harus menjadi bagian dari tujuan pembelajaran yang akan dicapai melalui kegiatan pembelajaran yang tepat. Menurut Popham, ranah afektif akan berdampak atas pencapaian hasil belajar seseorang. Seseorang yang tidak memiliki minat pada pelajaran tertentu, makaakan sulit untuk dapat mencapai keberhasilan belajar yang optimal Sebaliknya seseorang yang berminat pada suatu mata pelajaran dimungkinkan akan berdampak kearah hasil belajar yang optimal (Widyastuti dan Agung Putra, 2018). Sebagaimana yang di ungkapkan oleh 248 
ibu Nurul Hidayati selaku Guru IPS di SMPN 8 Pamekasan dalam hasil transkrip rekaman wawancara berikut ini:

\begin{abstract}
"Dampak dari penerapan strategi ini membuat siswa menjadi lebih disiplin terhadap semua kegiatan yang ada di sekolah ini, dikelas maupun diluar kelas. Contohnya seperti di pagi hari, mereka datang sebelum jam 7, kemudian di dalam kelas mereka mendengarkan dengan baik dan sangat antusias untuk menerima pembelajaran.ketika saya menjelaskan dan ketika saya memberikan pertanyaan mereka dengan semangat dan percaya diri untuk menjawabnya. Bisa dikatakan penerapan strategi ini sudah berhasil membuat mereka lebih baik lagi."
\end{abstract}

Berdasarkan paparan data tersebut dalam mengoptimalkan aspek afektif peserta didik ini sangat berdampak terhadap sikap siswa ketika berada di luar kelas maupun di dalam kelas yang dapat disimpukan sebagai berikut:

a) Guru IPS memberikan sebuah penanaman sikap yang disiplin dalam segala hal terhadap peserta didik, sehingga membuat siswa menjadi lebih disiplin. Seperti dalam hal disiplin waktu, peserta didik datang lebih awal diwaktu pagi karena peserta didik dibina oleh guru dan pihak sekolah akan pentinya displin waktu.

b) Dampak lain dari penerapan strategi untuk mengoptimalkan aspek afektif ini adalah antusias dalam pembelajaran dan lebih percaya diri untuk mengungkapkan idenya kepada teman sejawatnya. Sehingga berangkat dari kepercayaan diri itulah menyebabkan kelas menjadi aktif dan membuat siswa paham tentang apa yang dipelajarinya.

Dari perubahan yang nampak dalam diri peserta didik tidak lepas dari indikatorindikator dalam aspek afektif yang telah ditanamkan oleh guru IPS di SMPN 8 Pamkasan kepada peserta didik. Sebagaimana yang terdapat dalam Panduan Penilaian oleh Pendidikan dan Satuan Pendidikan Sekolah Menengah Pertama oleh Kementrian Pendidikan dan Kebudayaan, bahwa terdapat enam indikator dalam aspek afektif yang harus di optimalkan oleh guru, di antaranya:

a. Sikap jujur

Jujur adalah suatu sikap yang lurus hati, menyatakan yang sebenar-benarnya dan tidak berbohong atau berkata hal-hal yang menyalahi apa yang terjadi (fakta). Contoh dari penerapan sikap jujur di sekolah yang harus di terapkan oleh peserta didik adalahmengerjakan tugas atau ujian sekolah tanpa mencontek, tidak berbohong kepada guru atau teman-teman dan tidak mengambil barang milik teman.

b. Sikap disiplin 
Disiplin adalah suatu hal yang tercipta dan terbentuk melalui proses serangkaian kegiatan yang mengedepankan nilai-nilai ketaatan, kepatuhan, dan ketertiban. Contoh dari sikap disiplin jika berada di lingkungan sekolah adalahmasuk sekolah tepat waktu, berseragam dengan rapi, menaati tata tertib sekolah, mendengarkan pelajaran dengan baik membuang sampah pada tembatnya.

c. Sikap tanggung jawab

Sikap tanggung jawab adalah kesadaran manusia akan tingkah laku atau perbuatan baik yang disengaja maupun tidak. Contoh dari sikap tanggung jawab jika berada di lingkungan sekolah adalah mematuhi tata tertibsekolah, seperti menggunakan seragam dengan baik dan masuk sekolah tepat waktu menghormati guru, menjaga kebersihan sekolah, seperti membuang sampah.

\title{
Faktor pendukung dan penghambat strategi guru IPS dalam mengoptimalkan aspek afektif peserta didik di SMPN 8 Pamekasan
}

Setiap penerapan suatu strategi dalam pembelajaran tentu akan menemukan faktor pendukung dan penghambat selama strategi tersebut diterapkan. Sebagaimana yang sampaikan oleh ibu Nurul Hidayati selaku guru IPS di SMPN 8 Pamekasan dalam hasil transkrip rekaman wawancara berikut ini :

\begin{abstract}
"Ada beberapa faktor pendukung dalam strategi guru IPS untuk mengoptimalkan aspek afektif peserta didik yang pertama adalah kompetensi guru yang dapat memberikan pembelajaran yang mudah di pahami oleh peserta didik. Dalam hal ini guru yang memiki kompetensi yang bagus dapat menjelaskan dan juga menghubungkan materinya dengan kehidupan sehari-hari"

"Kedua adanya peraturan sekolah yang dijadikan buku tata tertib hal tersebut cukup berhasil untuk mendisplinkan peserta didik disini karena semua pelanggran ada skornya, kemudian ada peran dari guru bimbingan konseling yang membantu kita untuk mengoptimalkan aspek afektif peserta didik" "Ketiga kita ada program yang bernama paguyuban dimana setiap wali kelas mempunyai grup WhatsApp yang anggotanya adalah wali murid. Tujuan dari program tersebut agar wali kelas bisa menjalin komunikasi langsung dengan wali murid ketika ada keperluan yang berkaitan dengan putra-putrinya. Terkadang pihak sekolah mengundang wali murid untuk mensosialisasikan kegiatan sekolah yang memerlukan persetujuan wali murid."
\end{abstract}

Berdasarkan hasil wawancara di atas dapat diuraikan sebagai berikut:

a) tata tertib sekolah dapat memberikan sebuah aturan tertulis yang bisa mengontrol peserta didik agar displin.

b) Guru bimbingan konseling juga membantu guru IPS untuk mengoptimalkan aspek afektif peserta didik.

c) Sekolah tersebut memiliki sebuah program yang bernama paguyuban dimana program tersebut bisa mendekatkan wali kelas dengan wali murid melalui grup whatsapp.

Disamping kompetensi guru, tata tertib, peran guru bimbingan konseling, motivasi yang muncul dari dalam diri siswa sangat mempengaruhi masing-masing individu untuk 
melahirkan perubahan dalam dirinya dan lingkungan sekitarnya. Sebagaimana dalam petikan wawancara di bawah ini:

"Faktor yang paling mendukung untuk mengoptimalkan aspek afektif siswa itu adalah motivasi yang muncul dari dalam diri siswa, karena ketika siswa tersebut sudah memiliki keinginan untuk berubah ke atah yang lebih baik lagi, maka otomatis akan memudahkan untuk menuju perubahan itu. Selain itu, ketika salah satu siswa sudah memiliki motivasi agar menjadi siswa yang baik maka hal tersebutakan menular ke siswa yang lain atau teman-teman terdekatnya."

Motivasi dalam diri siswa menjadi pengaruh penting untuk memunculkan perubahan dalam diri siswa. Ketika seorang siswa sudah memiliki motivasi yang besar, maka mereka akan lebih mudah untuk berubah, sehingga sikap disiplin, sopan, tanggung jawab, dan sebagainya lebih mudah tertanam dalam diri siswa. Selain itu, tidak sedikit antara siswa yang satu mempengaruhi siswa yang lain. Sehingga ketika salah seorang siswa sudah memiliki perilaku yang baik, maka dapat mempengaruhi temannya.

Selain faktor pendukung, terdapat beberapa faktor yang menghambat guru IPS dalam megoptimalkan aspek afektif peserta didik sebagaimana yang disampikan oleh ibu Nurul Hidayati selaku guru IPS di SMPN 8 Pamekasan :

\footnotetext{
"Sebenarnya tidak hambatan yang berarti dalam penerapan strategi ini, hanya saja ada sedikit yang menurut saya masih bisa di perbaiki, misalnya perbedaan karakter setiap siswa. Menurut saya perbedaan ini ada banyak faktor entah itu dari latar belakang keluarganya, temantemannya,maupun lingkungannya. Sehingga dengan latar belakang tersebut bisa sedikit menghambat guru untuk mengoptimalkan aspek afektif peserta didik, karena ada keterbatasan waktu untuk memahami setiap karakter peserta didik. Tapi saya sebagai guru harus bisa berusaha lagi untuk lebih memperhatikan setiap karakter masing-masing peserta didik. Selain itu faktor yang cukup menghambat guru dalam mengoptimalkan aspek afektif ini adalah usia mereka, diusia mereka menurut saya masih berada pada fase dari anak-anak menuju remaja yaitu 13-15 tahun sehingga saat ini mereka itu masih mencari jati diri mereka. Sebagai seorang guru saya paham dan memaklumi itu."
}

Wawancara di atas menunjukkan bahwa karakter setiap siswa itu berbeda-beda yang dipengaruhi oleh beberapa faktor diantaranya sebagai berikut:

a) Dari latar belakang keluarga, teman-temannya dan lingkungan sekitarnya. Hal tersebut membuat guru merasa terhambat dalam mengoptimalkan aspek afektif peserta didiknya karena ada keterbatasan waktu untuk bertatap muka langsung antara guru dengan peserta didik.

b) Selain itu menurut beliau faktor yang cukup menghambat guru unuk mengoptimalkan aspek afektif adalah faktor usia, dimana peserta didik yang saat ini rentang usianya masih 13-15 tahun masih berada pada fase dari anak-anak menuju remaja sehingga saat ini mereka masih mencari jati diri. Maka disini perlu peran seorang guru yang bisa memahami dan bisa membimbing mereka kearah yang lebih baik lagi. 
Kesimpulan

Berdasarkan pembahasan dari hasil penelitian yang dilakukan oleh peneliti, maka dapat ditarik beberapa kesimpulan di antaranya sebagai berikut (1) Strategi guru IImu Pengetahuan Sosial dalam mengoptimalkan aspek afektif peserta didik di SMPN 8 Pamekasan dalam penerapnnya dilakukan ketika pelajaran berlangsung dan guru membaginya menjadi tiga tahap yaitu pra pembelajaran, pada saat pembelajaran dan pascapembelajaran. Pada saat pra pembelajaran guru IPS mengawali pembelajaran dengan menyiapkan rencana pelaksanaa pembelajaran (RPP) dan menyiapkan segala keperluan dalam pembelajaran seperti media pembelajaran. Setelah itu guru mengajak peserta didik untuk berdoa bersama dan kemudian guru memberikan sedikit pengantar yang didalamnya berisikan motivasi belajar agar bersemangat dalam menerima pembelajaran.

(2) Dampak dari penerapan strategi guru IPS dalam mengoptimalkan aspek afektif peserta didik di SMPN 8 Pamekasan dapat dilihat dari perubahan sikap peserta didik ketika di dalam kelas maupun di luar kelas. di dalam kelas peserta didik aktif dan antusias dalam menerima pembelajaran dari guru. Di luar kelas Strategi tersebut berdampak terhadap kedisplinan peserta didik dalam hal waktu dan dalam hal kerapian, terlihat sudah sangat jarang peserta didik yang datang terlambat ke sekolah dan dalam hal kerapian terlihat mereka sangat displin.(3) Faktor yang menjadi pendukung guru IPS dalam mengoptimalkan aspek afektif peserta didik di SMPN 8 Pamekasan diantaranya adalah sebagai berikut: a) Kompetensi guru b) Tata tertib sekolah c) Program yang bernama paguyuban d) Motivasi siswa e) Adanya dukungan dari wali muridf).Kegiatan Sosial g) Kegiatan keagamaan. Faktor yang menjadi penghambat guru IPS dalam mengoptimalkan aspek afektif peserta didik di SMPN 8 Pamekasan diantaranya adalah sebagai berikut: a) Perbedaan Karakter Peserta Didik b) Faktor keluarga c) Usia Peserta Didik d) Pengaruh Teman.

\section{Saran}

Saran yang ingin disampaikan peneliti kepada guru IPS di SMPN 8 Pamekasan adalah tetaplah profesional, kreatif dan inovatif dalam proses pembelajaran, konsisten dalam menerapkan strategi untuk mengoptimalkan asepek afektif peserta didik dengan penanaman sikap displin dan bertanggung jawab. Selain itu melakukan evaluasi secara berkala terhadap strategi yang diterapkan dan untuk Peserta didik tetaplah mempertahankan semua perilaku yang baik yang sudah ada dalam dirinya, namun tetap melakukan perbaikan dan pengoptimalan dari sisi lain,teruslah belajar hal-hal baru agar kelak menjadi seorang yang berguna bagi bangsa dan negara.

\section{Referensi}


Alifah,Fitriani Nur. (2019). Pengembangan Strategi Pembelajaran Afektif. Jurnal pendidikan, Vol. 5 No. 3.

Amri, Sofan dan lif Khoiru Ahmadi. (2010). Kontruksi Pengembangan Pembelajaran. Jakarta: Prestasi Pustakaraya.

Anggito., Albi., dan Johan Setiawan. Metodologi Penelitian Kualitatif. Sukabumi CV.Jejak, 2018.

Budiyantoro., Mangun. (2016). Guru ideal perspektif pendidikan islam. Yogyakarta: manajemen pendidikan islam.

Buna'l. (2006). Metodologi Penelitian Pendidikan. Pamekasan: STAIN. 2006.

Darmadji, Ahmad. (2014). Ranah Afektif Dalam Evaluasi Pendidikan Agama Islam, Penting Tapi Sering Terabaikan", jurnal pendidikan agama islam, Vol. 7 No.1.

Fitriani Nur. (2019). Pengembangan Strategi Pembelajaran Afektif. Jurnal UIN Sunan Kalijaga Yogyakarta, Vol. V, No. 1, Juni.

Gunawan Imam. (2013). Metode penelitian kualitatif Teori dan Praktik. Jakarta: Bumi Aksara.

Hardini, Isriani. (2015). Strategi pembelajaran terpadu. Yogyakarta: Familia.

Haryadi Toto. (2015). Melatih Kecerdasan Kognitif, Afektif, Dan Psikomotorik Anak Sekolah Dasar Melalui Perancangan Game Simulasi "Warungku”, Jurnal Desain Komunikasi Visual \& Multimedia, Vol.01 No.02 Tahun.

Hasyim, Adelina. (2015). Pembelajaran ilmu pengetahuan sosial berbasis karakter. Yogyakarta : Media akademi.

Kasiram, Moh. (2010). Metodologi Penelitian Kuantitatif-Kualitatif. Malang: UIN-Maliki Press. Kemendikbud. (2017). Panduan Penilaian oleh Pendidikan dan Satuan Pendidikan Sekolah Menengah Pertama. Jakarta: Kementerian Pendidikan dan Kebudayaan.

Lusiana Diyah. (2018). Instrumen Penilaian Afektif Pendidikan Karakter Bangsa Mata Pelajaran Pkn Smk", jurnal prodi Penelitian dan Evaluasi Pendidikan, Program Pascasarjana, Universitas Negeri Semarang, Vol 2 No 2 tahun.

Nurbudiyani lin. (2013). Pelaksanaan Pengukuran Ranah Kognitif, Afektif, Dan Psikomotor Pada Mata Pelajaran Ips Kelas lii Sd Muhammadiyah Palangkaraya. Jurnal Keguruan 
dan IImu Pendidikan Universitas Muhammadiyah Palangkaraya, Vol 13 Nomor 1, Desember.

Nurhidayati Aryanti. (2013). Peningkatan Hasil Belajar Ranah Afektif Melalui Pembelajaran Model Motivasional", Jurnal Pendidikan Teknik Bangunan, Jurusan Pendidikan Teknik dan Kejuruan, FKIP Kampus UNS Pabelan, Vol. VI No.2, Juli.

Permana, Septian Aji. (2017). Strategi Pembelajaran IPS Kontemporer. Yogyakarta: Media Akademi,.

Purnomo, Edy. (2016). Dasar-dasar dan perancangan evaluasi pembelajaran. Yogyakarta: Media Akademi.

RI, Departemen Agama. (2002). Al-Qur'an dan Terjemahnya. Jakarta: Darus Sunnah.

Rojuli,Subkhan. (2016). Strategi Pembelajaran IPS. Surabaya: CV. Garuda Mas Sejahtera,. Ruhimat Toto. (2019). Prosedur Pembelajaran. Jurnal kurikulum dan teknik pendidikan, vol. 10, no. 2.

Rukin. (2019). Metodologi Penelitian Kualitatif . Jakarta: Yayasan Ahmar Cendekia Indonesia,.

Solikin, Mochamat. (2014). Strategi Pembelajaran Afektif untuk Membentuk Karakter Bertanggungjawab bagi Santri kelas XII di Pondok Pesantren Pabelan Magelang Jawa Tengah”. Skripsi: Universitas Islam Negeri Sunan Kalijaga Yogyakarta, Yogyakarta.

Sudaryono. (2012). Dasar-Dasar Evaluasi Pembelajaran. Yogyakarta: Graha IImu.

Sugeng Widodo. (2018). Belajar dan pembelajaran. Yogyakarta: Graha IImu.

Sugiono. (2015). Metode Penelitian Kuantitatif, Kulaitatif, dan R\&D, cet, 22. Bandung: Alfabeta,.

Sukanti. (2011). Penilaian Afektif Dalam Pembelajaran Akuntansi” jurnal Pendidikan Akuntansi Universitas Negeri Yogyakarta, Vol. IX. No. 1 Tahun.

Suprihatiningrum,Jamil. (2016). Strategi Pembelajaran Teori dan Aplikasi. Yogyakarta: ArRuzz Media.

Syakroni,Muhammad. (2017). Strategi Pengembangan Ranah Afektif Dalam Pembelajaran Aqidah Akhlak pada Siswa Kelas VIII A di MTSN 1 Boyolali Tahun Pelajaran 2016/2017 . Skripsi: Institut Agama Islam Negeri Salatiga, Salatiga,. 
Tambak, Syahraini. (2013). Membangun bangsa melalui pendidikan, Gagasan Pemikiran dalam Mewujudkan Pendidikan Berkualitas untuk Kemajuan Bangsa Indonesia. Yogyakarta: Graha IImu,.

Undang-Undang Nomor 14 Tahun (2005) tentang Guru dan Dosen. Jakarta: t.p.

Warliah Wiwin, dkk. (2018). Pengembangan Media Pembelajaran Berbasis Widya Wisata. Pamekasan: Duta Media Publishing.

Wicaksono Rizky. (2011). Strategi Penerapan Domain Afektif Di Lingkup Perguruan Tinggi. Jurnal Pendidikan, Volume 12, Nomor 2, September.

Widyastuti dan Agung Putra Wijaya. (2018). Dasar-dasar dan perencanaan evaluasi pembelajaran. Yogyakarta: Graha IImu.

Yusuf, A. Muri. (2014). Metode Penelitian: Kuantitatif, Kualitatif, dan Penelitian Gabungan Jakarta: Kencana. 
Agung Widiyanto, Sahrul Romadhon 